\title{
FOLIAR CARBOHYDRATES CONTENT AND INVERTASE ACTIVITY IN VINES AT SÃO FRANCISCO RIVER VALLEY - BRAZIL ${ }^{1}$
}

\author{
BARBARA FRANÇA DANTAS ${ }^{2}$, LUCIANA DE SÁ RIBEIRO ${ }^{3}$, ALEXANDRO PEREIRA DA SILVA $^{3}$, \\ SARA RAQUEL DE SOUZA LUZ
}

\begin{abstract}
The irrigated agriculture at the São Francisco River Valley, Northeast Brazil, shows an increasing production of grapes for winery. Among the wines produced there the one obtained from Vitis vinifera L., cultivar Syrah, stands out due to its adaptation to the climatic conditions of the region. However, little is known about carbohydrates metabolism of vines cultivated in this region. The objective of this work was to evaluate sugar and starch contents and the invertase activity in vines leaves during two consecutive growing seasons. The experiment was carried out at Embrapa Semi-Árido and at Santa Maria Winery, respectively located in Petrolina and Lagoa Grande, Pernambuco-Brazil. Leaves were collected weekly from January to December of 2003 and assessed for reducing sugars, total soluble sugars and starch contents, as well as for acid (AI) and neutral invertases (NI). The results showed that reducing sugars, total soluble sugars and starch contents increased during fruit maturation and are influenced by temperature, radiation and insolation variations. The second growing season showed higher reducing sugars and total soluble sugars content and lower starch content in the leaves than the first one. AI activity was higher than NI activity and these also varied according to weather conditions. During berries ripening, leaves showed higher sugar content and invertase activity, suggesting a higher sugar metabolism and transport during this phase.
\end{abstract}

Key words: grape, metabolism, sugar

\section{TEORES FOLIARES DE CARBOIDRATOS E ATIVIDADE DE INVERTASES EM VIDEIRAS NO VALE DO RIO SÃO FRANCISCO- BRASIL}

RESUMO - O pólo de agricultura irrigada do Vale do Rio São Francisco apresenta um crescente aumento na produção de uvas para vinificação. Entre os vinhos finos produzidos na região, destaca-se aquele obtido da cultivar Syrah, que se adaptou bem às condições climáticas da região. Pouco se conhece, no entanto, sobre o metabolismo de carboidratos das videiras nessa região. O objetivo deste trabalho foi avaliar os teores de açúcares e de amido, bem como a atividade de invertases durante dois ciclos de produção consecutivos. O experimento foi realizado na Embrapa Semi-Árido e na Vitivinícola Santa Maria, localizadas, respectivamente, em Petrolina e Lagoa Grande-PE. Semanalmente, de janeiro a dezembro de 2003, foram coletadas folhas para análise de teores de açúcares redutores, açúcares solúveis totais e amido, bem como ensaios de invertase ácida (AI) e neutra (NI). Os resultados indicam que os teores foliares de açucares redutores, açúcares solúveis totais e amido aumentaram durante a maturação dos cachos, acompanhando as variações da temperatura, radiação solar e insolação. O ciclo de produção do segundo semestre apresentou maiores teores de açúcares redutores e açúcares solúveis totais e menores teores de amido que o ciclo de primeiro semestre. A atividade de AI foi maior que a de NI, e estas também variaram de acordo com as condições climáticas. As fases de maturação de frutos apresentaram maiores teores de açúcares e maior atividade de invertases nas folhas, indicando um alto metabolismo e transporte de açúcares durante essa fase.

Palavras-chave: açúcares, metabolismo, uva

\section{INTRODUCTION}

Photosynthetically active source of tissues, such as mature leaves produce more carbohydrates than they require and thus export assimilates as sucrose to photosynthetically less active or inactive tissues, such as young leaves, roots, fruits or canes. However, source /sink relations are not static. During vegetative growth, most carbohydrates are imported into the roots and young leaves, whereas after flowering, carbohydrates are mainly directed into the developing fruits tuber and storage roots (Roitch et al., 2003).

The degradation of sucrose can be catalyzed by at least two different classes of enzymes. A reversible cleavage of sucrose is catalyzed by sucrose synthesis (EC 2.4.1.13); in contrast, invertases (EC 3.2.1.26) catalyze the irreversible cleavage of sucrose to glucose and fructose. Among the carbohydrate metabolizing enzymes, the invertases are a group of $\beta$-fructosidases eventually classified according to the isoelectric point, $\mathrm{pH}$ optimum for activity (acidic, neutral or alkaline), solubility (soluble or insoluble) and cellular localization (Quick, 1996; Nascimento et al., 1998). Thus invertases are classified in three main groups: extra cellular invertases which are characterized by a low $\mathrm{pH}$ optimum, are ionically bound to the cell wall and are responsible for phloem unloading in growing tissues (Roitsch et al., 2003); vacuolar invertases which are soluble, are characterized by an acidic $\mathrm{pH}$ optimum and are shown to regulate vacuolar sucrose levels (Ohyama et al., 1995) and cytosolic invertases which have a neutral or alkaline $\mathrm{pH}$ optimum and acts as a citosol sucrose level 'maintenance' enzyme (Richardo et al., 1970). According to Hunter et al. (1994) and Palliotti \& Cartechini (2001), the hexoses (glucose and fructose) and the sucrose contents, as well as the activity of carbohydrate metabolizing enzymes in grapevine (Vitis vinifera L.) leaves, they are influenced by seasonal and phenological changes. Plant invertase gene expression and enzyme activity are both known to be influenced by a variety of intracellular and extra cellular factors (Tymowska-Lalanne \& Kreis, 1998), such as environmental conditions, plant hormones and phenological stages (Roitsch et al., 2000, 2003).

The viticulture and winery belt at São Francisco River Valley, located between the parallels of latitude $9^{\circ}$ and $10^{\circ}$ south, is the unique wine producing region in the world with a semi-arid tropical climate, classified as "BSh" according to Köeppen. "B" means a climate in which evaporation is higher than precipitation, " $\mathrm{S}$ " characterizes lack of rain or a semi-arid condition and " $\mathrm{h}$ " is referred to low amplitude of temperatures of the hottest and coldest month of the year (Coelho, 1992). Thus this climate condition of wine grapes production, in which temperatures are always above $12^{\circ} \mathrm{C}$ and it is possible to have 2.5 harvests per year, is completely different from other wine producing regions.

The objective of this work was to evaluate the seasonal and phenological effects on sugar content and invertase activity in leaves

\footnotetext{
1 (Trabalho 172/2004). Recebido: 10/10/2004. Aceito para publicação: 21/08/2005.

2 Embrapa Semi-Árido, C.P. 23, CEP 56302-970, Petrolina-PE, Brasil, Fone.: (87)3862-1711; barbara@cpatsa.embrapa.br.

3 UPE/FFPP, Petrolina-PE, Bolsista PIBIC - FACEPE/CNPq.

${ }^{4}$ Engenheira Agronômica, Bolsista BTT-FACEPE.
} 
of Vitis vinifera L. cv. Syrah, during two consecutive growing seasons of 2003.

\section{Material and Methods}

The experiment was conducted at the Embrapa Semi-Árido (laboratory analysis), Petrolina and at a 4.13 ha vineyard located in Santa Maria Winery, Planaltina Farm, Lagoa Grande, both in Pernambuco State-Brazil. The studied grapevines cultivar Syrah, were 11 years old; cordons trained and spur pruned, spaced $1.20 \mathrm{~m}$ between plants and 3.5 $\mathrm{m}$ among rows with dripper irrigation.

The leaves opposite to the clusters were collected weekly from 4 plants (4 replications), in a totally randomized design, during two consecutive growing seasons. The first growing season (GS1) occurred from December 24, 2002 to June 8, 2003 and the second (GS2) from June 8 to December 3, 2003. The leaves were collected 28 and 22 days after the pre-season pruning for GS1 and GS2, respectively. The samples were stored at $-20^{\circ} \mathrm{C}$ until extraction and analysis of the reducing sugars, total soluble sugars and starch and acid and neutral invertases (AI and NI, respectively) were performed.

For the extraction of reducing sugars, total soluble sugars and starch, the frozen leaves were homogenized in distilled water in mortar and pestle (1:10, weight: volume) and centrifuged at 2,500 $\mathrm{xg}$ for $10 \mathrm{~min}$. The supernatant was used for total soluble sugars and reducing sugars analysis and the pellet was used for starch extraction (Allen et al., 1977).

Total soluble sugars and starch were quantified by the anthrone method at $620 \mathrm{~nm}$, as proposed by Morris (1948) and Yemm \& Willis (1954) and reducing sugars were quantified by the dinitrosalicylic method at $540 \mathrm{~nm}$, as proposed by Miller (1959).

The extraction and assay of AI and NI were carried out according to the methodology proposed by Nascimento et al. (1998). The extraction was done in $50 \mathrm{mmol} \mathrm{L}^{-1} \mathrm{KH}_{2} \mathrm{PO}_{4} / \mathrm{K}_{2} \mathrm{HPO}_{4}$, $\mathrm{pH} 7.0$ buffer; $0.7 \%$ mercaptoethanol and $5 \mu \mathrm{mol} \mathrm{L}{ }^{-1} \mathrm{MnSO}_{4}$ The suspension was filtered with gauze, saturated in $50 \%\left(\mathrm{NH}_{4}\right)_{2} \mathrm{SO}_{4}$ at $5^{\circ} \mathrm{C}$ during $18 \mathrm{~h}$ and centrifuged at $4^{\circ} \mathrm{C}, 15,500 \mathrm{xg}$, during $30 \mathrm{~min}$. The pellet was re-suspended in $5 \mathrm{~mL}$ of extraction buffer, obtaining the crude extract, which was frozen at $-20^{\circ} \mathrm{C}$ until assays were performed. The $\mathrm{AI}$ and $\mathrm{NI}$ assays were performed in a reaction medium composed by $0.5 \mathrm{~mL}$ crude extract; $2.5 \mathrm{~mL}$ of $50 \mathrm{mmol}$ $\mathrm{L}^{-1} \mathrm{KH}_{2} \mathrm{PO}_{4} / \mathrm{K}_{2} \mathrm{HPO}_{4} \mathrm{pH} 7.0$ buffer for NI or $50 \mathrm{mmol} \mathrm{L}^{-1}$ sodium citrate buffer, pH 5.0 for AI and $1.0 \mathrm{~mL}$ of $100 \mathrm{mmol}^{-\mathrm{L}^{-1}}$ sucrose substrate. The reaction medium was incubated in a water bath at $35^{\circ} \mathrm{C}$, during $30 \mathrm{~min}$. After that the reducing sugars content in the reaction medium was quantified (Miller, 1959) and the AI and NI activities was expressed in reducing sugars produced $(\mu \mathrm{mol})$ per minute in $1 \mathrm{~g}$ of leaf fresh matter. During the trials, daily climate data were collected from the Agrometeorological Station at Bebedouro Experimental Field (PetrolinaPE $09^{\circ} 09^{\prime} \mathrm{S}, 42^{\circ} 22^{\prime} \mathrm{W}$ ).

\section{RESULTSAND DISCUSSION}

Many authors observed that both weather conditions and phenological phases control grapevine leaves photosynthesis and, therefore, influence carbohydrate production and transport (Hunter et al., 1994; Schier et al., 2000; Ferree et al., 2001; Dantas et al., 2003). In addition, the duration of each phenological phase of various grape cultivars for table at São Francisco River Valley, depends on the pruning date and the weather conditions (Leão \& Silva, 2003).

The duration of phenological stages were evaluated in the cv. Syrah during two growing seasons- GS (Table 1). The results showed that GS2 demanded more days to achieve ripe berries (106 DAP) as compared to GS1 (99 DAP). Due to a higher values of soluble solids thus achieving better quality wines. The berries were harvested overripped, 22 and 39 days after complete ripening as showed in Table 1.

The minimum, maximum and mean temperatures during the trials, exhibited in Figure 1, demonstrated that in spite of low temperature variation during the year, the GS1 started with higher temperatures that decreased at the end of the season. In contrast, GS2 started with increasing temperatures and the highest occurred at the end of the season. During veraison, the GS2 temperatures overcome GS1 temperatures. The same occurred with radiation values during the two GSs studied (Figure 2). As observed in Figure 3, in GS2 (July-December

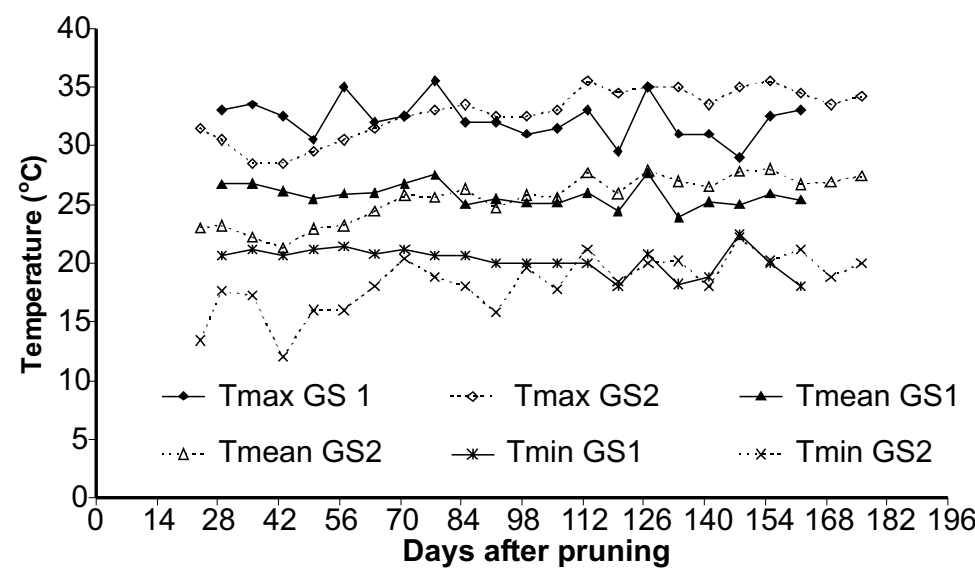

FIGURE 1 - Maximum (max), minimum (min) and mean (aver) temperatures $\left({ }^{\circ} \mathrm{C}\right)$ obtained at Bebedouro Agrometeorological Station during two growing seasons (GS) from December 2002 to December 2003. Petrolina-PE, April 2004.

2003), the insolation values (hours of sun during the day) were higher than in GS1, with the highest point at the GS2 veraison.

Only the reduced sugar contents and both acid (AI) and neutral invertase (NI) activities in Syrah grapevine leaves were positively correlated with maximum and mean temperatures, as well as with radiation. On the other hand, total soluble sugar content was negatively correlated with minimum temperature. There was no relationship between carbohydrate metabolism and insulation. Furthermore, the leaf starch content did not correlate with any weather parameter. Invertase activities were highly correlated to number of DAP, indicating a correlation with phenological phases (Table 2). According to Zufferey et al. (2000) and Schier et al. (2000), high temperatures, insolation or radiation along GS contribute to higher sugar concentration in leaves due to great photosynthesis activity and sugar transport. In this experiment, higher value of maximum and mean temperature and also higher radiation during

TABLE 1 - Phenological phases of the cv. Syrah grapevines at the two growing seasons evaluated. Petrolina- PE, April 2004.

\begin{tabular}{|c|c|c|c|c|c|}
\hline \multicolumn{3}{|c|}{$\begin{array}{c}\text { Growing season } 1 \\
\text { (GS1) }\end{array}$} & \multicolumn{3}{|c|}{$\begin{array}{c}\text { Growing season } 2 \\
\text { (GS2) }\end{array}$} \\
\hline Date & DAP $^{*}$ & Development stages & Date & DAP & Development stages \\
\hline $12 / 24$ & 0 & Pre- GS1 pruning & $06 / 08$ & 0 & Pre- GS2 pruning \\
\hline $12 / 30$ & 6 & Budburst & $06 / 17$ & 9 & Budburst \\
\hline $01 / 22$ & 29 & Bloom & $07 / 14$ & 36 & Bloom \\
\hline $01 / 29$ & 36 & Fruit set & $07 / 21$ & 43 & Fruit set \\
\hline $03 / 12$ & 78 & Veraison & $09 / 05$ & 89 & Veraison \\
\hline $04 / 02$ & 99 & Ripe berries & $09 / 22$ & 106 & Ripe berries \\
\hline $04 / 24$ & 121 & Harvest & $10 / 31$ & 145 & Harvest \\
\hline $06 / 08$ & 166 & Pruning & $12 / 03$ & 178 & Pruning \\
\hline
\end{tabular}


TABLE 2 - Correlations between sugar contents, invertase activity in grapevine leaves and weather and phenological parameters during two growing seasons from December 2002 to December 2003. Petrolina-PE, April 2004.

\begin{tabular}{|c|c|c|c|c|c|c|}
\hline & $\mathrm{DAP}^{(1)}$ & Tmean $^{(2)}$ & Tmax & Tmin & Insolation & Radiation \\
\hline Acid Invertase & $0,6852 * *$ & $0,3961 * *$ & $0,4155^{* *}$ & $0,0494^{\mathrm{ns}}$ & $0,2875^{\mathrm{ns}}$ & $0,3464^{*}$ \\
\hline Neutral Invertase & $0,6186^{* *}$ & $0,4283 * *$ & $0,4647 * *$ & $0,0623^{\mathrm{ns}}$ & $0,3142 *$ & $0,4086^{* *}$ \\
\hline Reduced Sugar & $-0,1563^{\mathrm{ns}}$ & $0,4728 * *$ & $0,4791 * *$ & $0,1957^{\mathrm{ns}}$ & $0,2434^{\text {ns }}$ & $0,3295^{*}$ \\
\hline Total Soluble Sugar & $-0,4236^{*}$ & $-0,2355^{\mathrm{ns}}$ & $0,0575^{\mathrm{ns}}$ & $-0,455 * *$ & $0,12641^{\mathrm{ns}}$ & $-0,0059^{\mathrm{ns}}$ \\
\hline Starch & $0,2355^{\mathrm{ns}}$ & $0,0608^{\mathrm{ns}}$ & $0,0058^{\text {ns }}$ & $0,1219^{\mathrm{ns}}$ & $0,0021^{\mathrm{ns}}$ & $-0,0374^{\mathrm{ns}}$ \\
\hline
\end{tabular}

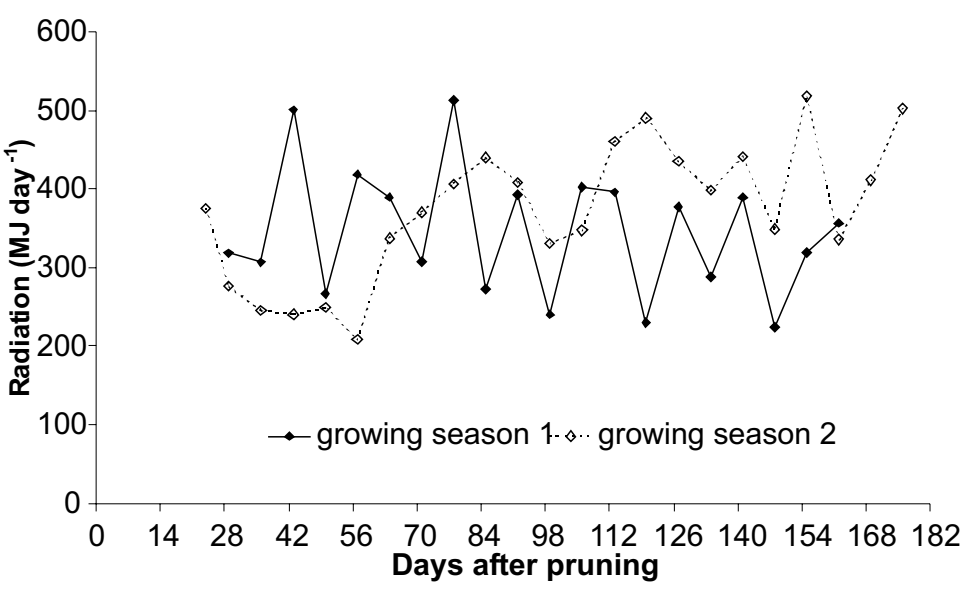

FIGURE 2 - Radiation (MJ.day $\left.{ }^{-1}\right)$, obtained at Bebedouro Agrometeorological Station during two growing seasons from December 2002 to December 2003. Petrolina-PE, April 2004.

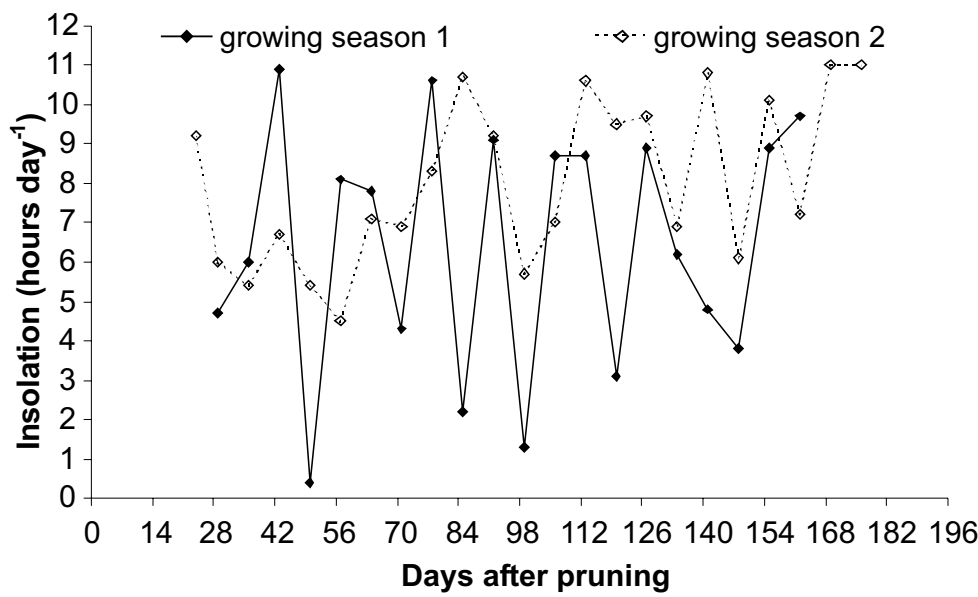

FIGURE 3 - Insolation (hours day ${ }^{-1}$ ) obtained at Bebedouro Agrometeorological Station during two growing seasons from December 2002 to December 2003. Petrolina-PE, April 2004.

GS2 induced higher NI and AI activities, as well as higher reduced sugar contents.

The reduced sugar contents in Syrah grapevine leaves increased until veraison for GS1 (78 DAP), decreasing after that. On the other hand, GS2 showed an increasing reduced sugar foliar content until fruit set (36 DAP), at 56 DAP, the reduced sugar content in leaves decreased abruptly and increased again until 98 DAP (Figure 4). Although the abrupt decrease of leaves reducing sugar content during fruit maturation, probably caused by low radiation and isolation values (Figures 1 and 2), both seasons presented similar patterns (Figure 4). Total soluble sugar contents showed an increase in both seasons during berries growth, before veraison. From veraison to harvest, the leaves total soluble sugar contents had opposite response in both seasons. In GS1, leaf total soluble sugar content had a great decrease until ripe fruits (99 DAP) increasing after harvest (121 DAP), while in GS2 these contents kept decreasing until pruning at 178 DAP (Figure 5). Leaf starch content were very low ( $2 \mathrm{mg} \mathrm{g}^{-1}$ of leaf fresh weight) at fruit set and increased 8 fold during fruit growth. During fruit

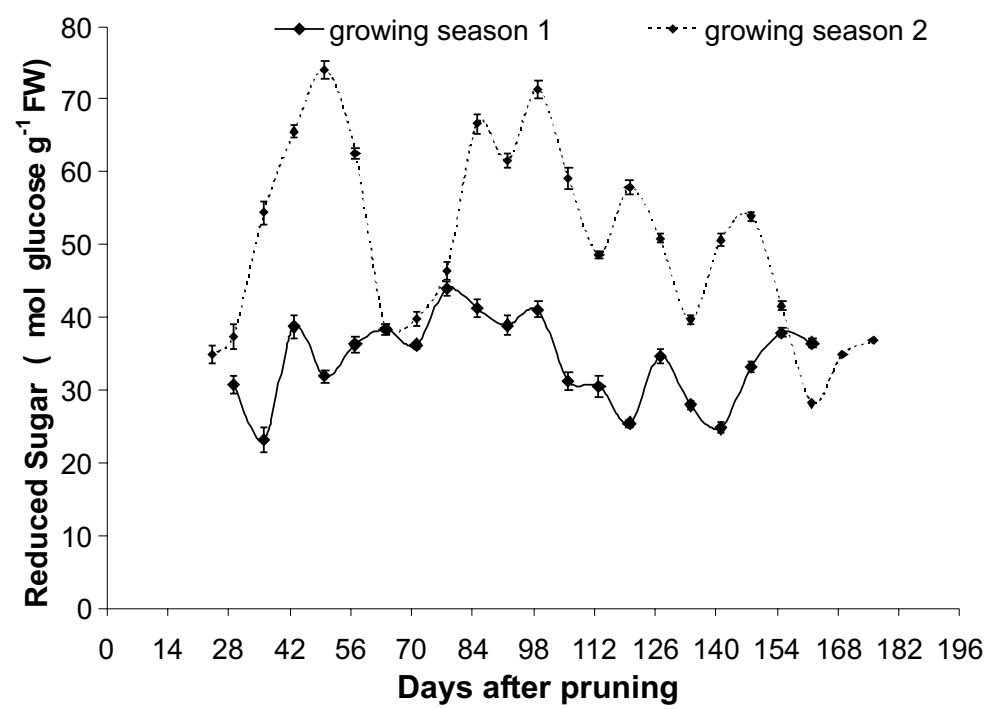

FIGURE 4 - Reduced sugar content in 'Syrah' leaves during two growing seasons (GS) from December 2002 to December 2003. Petrolina-PE, April 2004.

Vertical bars correspond to mean standard error

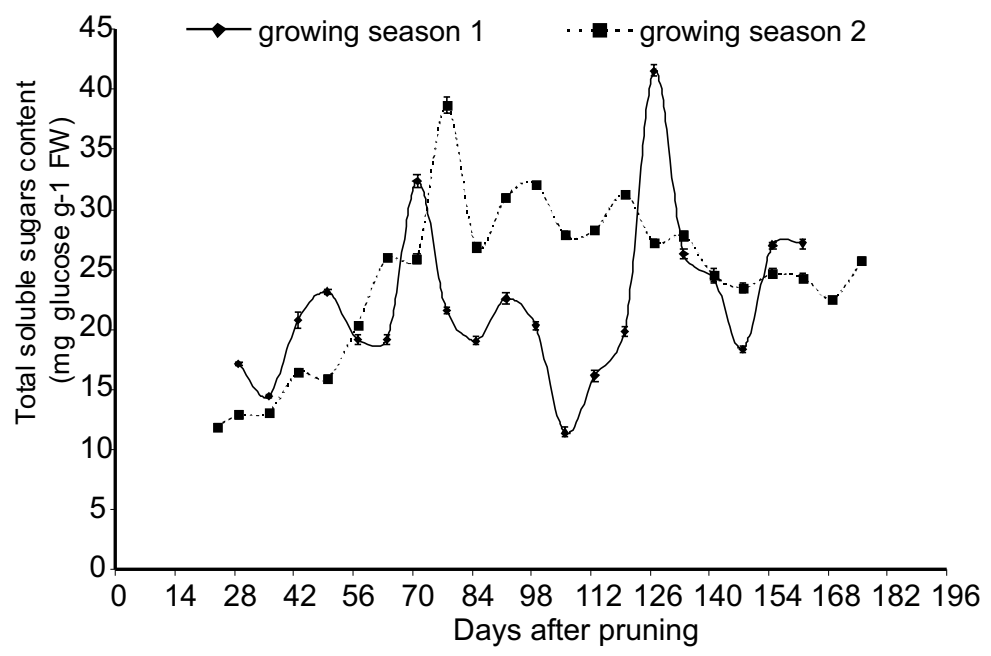

FIGURE 5 - Total soluble sugar content in 'Syrah' leaves during two growing seasons (GS) from December 2002 to December 2003.Petrolina-PE, April 2004.

Vertical bars correspond to mean standard error.

maturation, due to great sugar transport from leaves to berries, the leaf starch accumulation decreased (Figure 6).

According to Schier et al. (2000), the temperature influences the phloem transport, both simplasmic and apoplasmic. In this experiment GS2, with higher temperatures, probably had higher phloem transport activity, storing less starch in the grapevine leaves. In addition, the reduced sugar and total soluble sugar contents in the Syrah leaves were lower and the starch contents were similar or superior in GS1 than in GS2 (Figures 4, 5 and 6).

Hunter et al. (1994) verified that the glucose and fructose (reduced sugars) content intensified in both apical and basal grapevine leaves of 'Müller-Thurgau' (Riesling x Silvaner) throughout fruits 


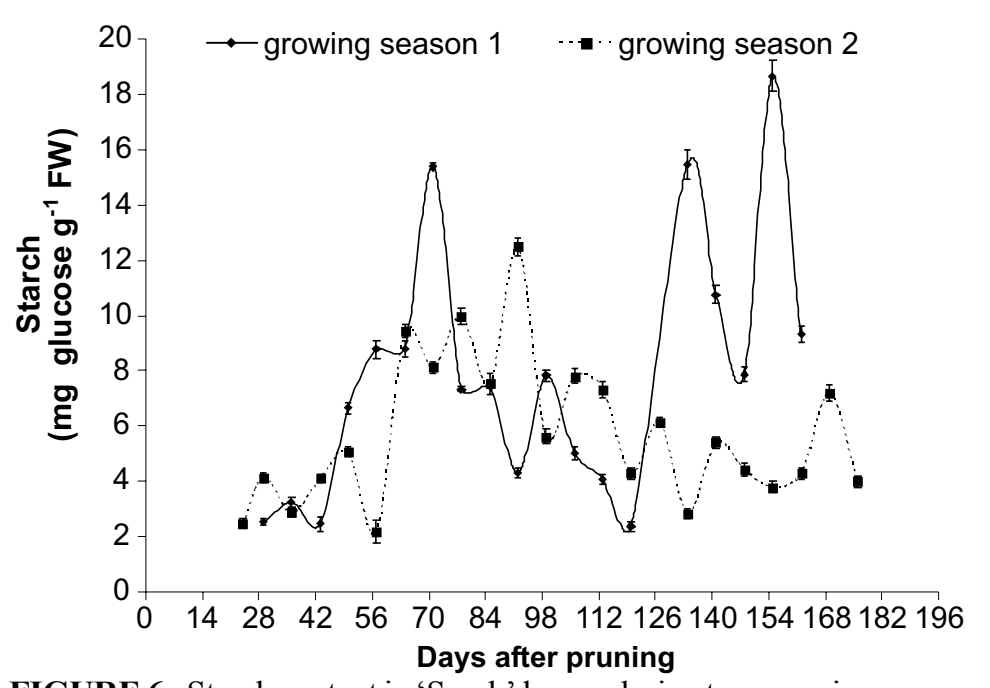

FIGURE 6 - Starch content in 'Syrah' leaves during two growing seasons (GS) from December 2002 to December 2003.Petrolina-PE, April 2004

Vertical bars correspond to mean standard error.

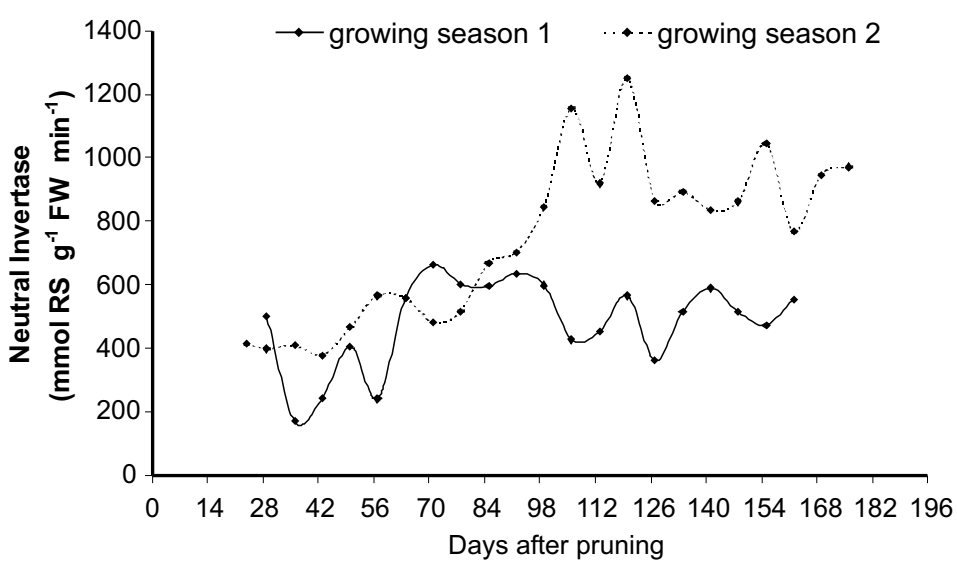

FIGURE 7 - Neutral invertase (NI) activity in 'Syrah' leaves during two growing seasons (GS) from December 2002 to December 2003.Petrolina-PE, April 2004.

Vertical bars correspond to mean standard error.

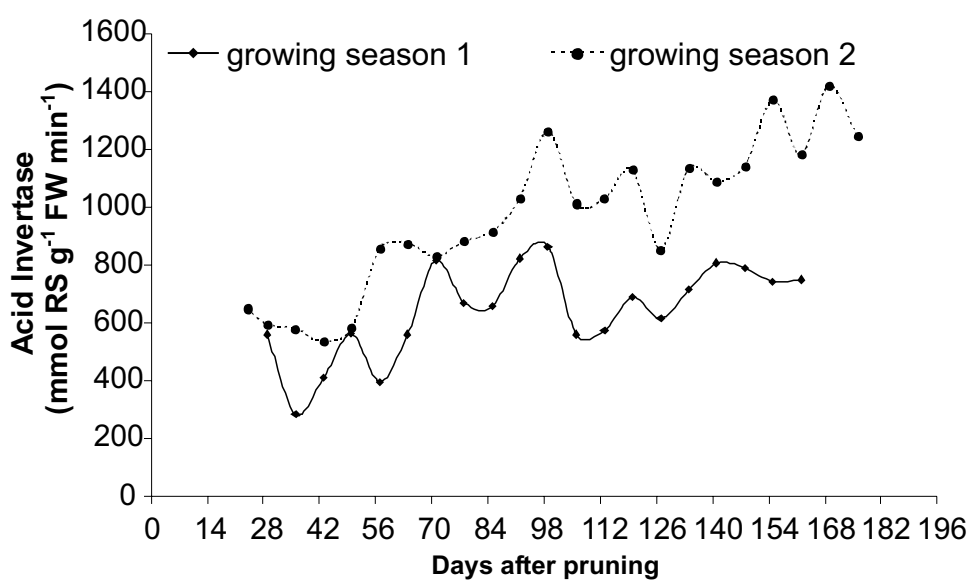

FIGURE 8 - Acid invertase (AI) activity in 'Syrah' leaves, during two growing seasons (GS) from December 2002 to December 2003. Petrolina-PE, April 2004.

Vertical bars correspond to mean standard error.

maturation, from veraison to ripe berries, and then decreases at the end of the GS, in agreement with our experiment. On the other hand, the sucrose (great percentage of the total soluble sugar in leaves) showed an inverse pattern when compared to reduced sugar as described by Hunter et al. (1994), this statement agrees with total soluble sugar pattern during this experiment.

The leaves acid invertase (AI) and neutral invertase (NI) activities showed a similar pattern for both seasons. In GS1, the invertase activity increased during berries growth. During ripening, the leaves maintained high invertase activities and decreased at the end of maturation (soluble solids content around $17^{\circ}$ Brix) and held similar values until pruning. In GS2, there was an increasing invertase activity during all season (Figures 7 and 8). The mean standard error inserted to the AI and NI activity curves was very low, indicating good analysis accuracy (Figures 7 and 8).

Pimentel (1998) stated that the activities of the acid invertase (AI) and the neutral invertase (NI) are higher in sink tissues, such as meristems, young leaves, roots and ripening fruits. The author also affirms that when the fruit growth rate is maximum, these are preferential sinks and receives a great amount of sucrose transported from photosynthesizing leaves and hydrolyzed by invertases. Therefore, according to this author, leaves would present low invertase activity, consuming little sucrose during ripening (Pimentel, 1998). However, there are disagreements about this affirmative. Foyer et al. (1997) verified that the invertase activity in leaves plays an important role in carbohydrate metabolism of source cells, by regulating sucrose levels in citosol and amplifying information about carbon status, as well as regulating sucrose transport, if mainly symplasmic or apoplasmic. Hunter et al. (1994) observed high invertase activity in leaves of 'MüllerThurgau' grapevines before the onset of ripening and low activity after veraison. This is confirmed in this experiment, disagreeing with Pimentel (1998), in which the grapevines showed high leaf invertase activities during ripening, 79-99 DAP for GS1 and 89-106 DAP for GS2. During GS2, however, the AI and NI activities were increased following temperature, radiation and insulation (Figures 7 and 8). According to Ferree et al. (2001), variations in light intensities can affect photosynthesis, transpiration and leaf specific weight in 'Vidal Blanc' and 'Chambering' grapevines, and thus affect sugar amount in leaves, as well as the sucrolytic enzymes.

In this experiment, it was demonstrated that AI activity was higher than NI activity in all evaluation dates. AI, nevertheless, can be soluble when located at the vacuole or insoluble when bonded to the cell wall. Dantas et al. (2003) suggested that the activity of cell wall acid invertase (CWAI) is lower than vacuolar acid invertase (VAI) in 'Syrah' and 'Moscato Cannelli' grapevines, and also that both AIs have different responses to crop management and seasonal variations.

Some authors (Huber, 1989; Scholes et al.,1996) raised an hypothesis that the activity of VAI regulates the sucrose status in leaves. Therefore, high VAI activity would reduce the amount of sucrose available for both storage and export, while low VAI activity would favor sucrose accumulation. However, the data obtained by KingstonSmith et al. (1998) suggested that no simple relationships exist between leaf sucrose and invertase, and that hexose accumulation is tightly regulated rather than reflecting directly the activity of VAI.

Regarding these features of the carbohydrate metabolism, some authors presented similar results in former works and also related them to leaves senescence, climate conditions, changes in source/sink relations and leaf exposition to radiation (Kriedemann \& Smart, 1971; Hunter \& Visser, 1988a, b, c).

There are few studies in the literature concerning to carbon metabolism at biochemical level in field grown grapevines (Hunter et al., 1994; Ferree et al., 2001). Furthermore, these few works were carried out in subtropical regions that could not be totally applied to tropical semi-arid conditions such as northeastern Brazil, which has expanding viticulture and winery. Other studies about carbohydrate metabolism in leaves, berries, canes and buds, must be carried out aiming to evaluate physiological and biochemical responses of grapevines at São Francisco River Valley.

\section{CONCLUSION}

Some important aspects of carbohydrate metabolism, such as sugar (reduced sugar, total soluble sugar and starch) storage and 
invertase activity in leaves of 'Syrah' grapevines cultivated at the region of the São Francisco River Valley, are modified according to the grapevines phenology and the temperature and sun conditions in which grapevines grow.

\section{ACKOWLEDGMENTS}

The authors wish to thank the Banco do Nordeste for the financial support to study carbohydrates metabolism at the São Francisco River Valley; the Fundação de Apoio à Pesquisa e Agronegócio Brasileiro (Fagro), for the resources management and the Fundação de Amparo à Ciência e Tecnologia do Estado de Pernambuco (Facepe) for scholarships provided. Special thanks to Dr. Luiza Helena Duenhas, Dr. Cláudia Rita de Souza and Dr. Eduardo Assis Menezes for critical reading of the manuscript.

\section{REFERENCES}

ALLEN, S.E.; GRIMSHAW, H.M.; PARKINSON, J.A.; QUARMBY, C. Chemical analysis of ecological materials. Oxford: Blackwell Scientific, 1977. 127p.

COELHO, M.A. Clima. In: COELHO, M.A. Geografia do Brasil. 3. ed São Paulo: Moderna, 1992. p.6-78.

DANTAS, B.F.; RIBEIRO, L.S.; SILVA, A.P.; RIBEIRO, R.A.M.; LUZ, S.R.S. Atividades de invertases em folhas de videiras 'Syrah' e 'Moscato Canelli' durante o período de formação. In: CONGRESSO BRASILEIRO DE VITICULTURA E ENOLOGIA, 10., 2003. Bento Gonçalves. Anais... Bento Gonçalves: EMBRAPA Uva e Vinho, 2003.p.179.

FERREE, D.C.; MCARTNEY, S.J.; SCURLOCK, D.M. Influence of irradiance and period of exposure on fruit set of French-American hybrid grapes. Journal of the American Society of Horticultural Science, Alexandria, v.126, n.3, p. 283-290, 2001.

FOYER, C.; KINGSTON-SMITH, A.; POLLOCK, C. Sucrose and invertase, an uneasy alliance. Iger Innovations. 1997. Disponível em: <http://www.iger.bbsrc.ac.uk/Publications/Innovations/in97/ Ch3.pdf $>$. Acesso em: 10 out. 2003.

HUBER, S.C. biochemical mechanism for regulation of sucrose accumulation in leaves during photosynthesis. Plant Physiology, Bethesda, v.91, p. 656-662, 1989.

HUNTER, J.J.; SKRIVAN, R.; RUFFNER, H.P. Diurnal and seasonal changes in leaves of Vitis vinifera $\mathrm{L}$ : $\mathrm{CO}_{2}$ assimilation rates, sugar levels and sucrolitic enzyme activity. Vitis, Siebeldingen, v.33, p. 189-195, 1994.

HUNTER, J.J.; VISSER, J.H. Distribuition of ${ }^{14} \mathrm{C}$-photosynthate in the shoot of Vitis vinifera L. cv Cabernet Sauvignon. I. The effect of leaf position and developmental stage of the vine. South African Journal of Enology and Viticulture, Stellembosch, v.9, n.1, p.3-9, 1988a.

HUNTER, J.J.; VISSER, J.H. Distribuition of ${ }^{14} \mathrm{C}$-photosynthate in the shoot of Vitis vinifera L. cv Cabernet Sauvignon. I. The effect of partial defoliation. South African Journal of Enology and Viticulture, Stellembosch, v.9, n.1, p.10-15, 1988b.

HUNTER, J.J.; VISSER, J.H. The effect of partial defoliation, leaf position and developmental stage of the vine on the photosynthetic activity of Vitis vinifera L. cv Cabernet Sauvignon. South African Journal of Enology and Viticulture, Stellembosch, v.9, n.2, p.9-15, 1988c.

KINGSTON-SMITH, A.H., GALTIER, N., POLLOCK, C.J.; FOYER, C.H. Soluble acid invertase activity in leaves is independent of species difference in leaf carbohydrates, diurnal sugar profile and paths of phloem loading. New Phytologist, Cambridge, n.139, p.283-292, 1998.

KRIEDEMANN, P.E.; SMART, R.E. Effect of irradiance, temperature and leaf water potential on photosynthesis of vine leaves. Photosynthetica, Prague, n.5, p. 6-15. 1971

LEÃO, P. C. de S.; SILVA, E. E. G. da. Caracterização fenológica e requerimentos térmicos de variedades de uvas sem sementes no Vale do São Francisco. Revista Brasileira de Fruticultura, Jaboticabal, v.25, n.3, p.379-382, 2003.

MILLER, G.L. Use of dinitrosalicylis acid reagent for determination of reducing sugars. Analytical Chemistry, Washington, v.31, p.426428,1959

MORRIS, D.L. Quantitative determination of carbohydrates with Drywood's anthrone reagent. Science, Washington, v.107, p.254255,1948

NASCIMENTO, R.; MOSQUIM, P.R.; ARAÚJO, E.F.; SANTANNA, R. Distribuição de amido, açúcares solúveis e atividades de invertases em explantes de soja sob várias concentrações de sacarose e diferentes fontes de nitrogênio. Revista Brasileira de Fisiologia Vegetal, Brasília, v.10, n.2, p.125-130. 1998.

OHYAMA, A.; ITO, H.; SATO, T.; NISHIMURA, S.; IMAI, T.; HIRAI, M. Supression of acidic invertase activity by antisense RNA modifies the sugar composition of tomato fruit. Plant and Cell Physiology, Kamikyo-Ku, v.36, p. 369-376. 1995.

PALLIOTTI, A.; CARTECHINI, A. Developmental changes in gas exchange activity in flowers, berries and trendils of field-grown Cabernet Sauvignon. American Journal of Enology and Viticulture, Davis, v.54, n. 4, p.317-323, 2001.

PIMENTEL, C. Metabolismo de carbono na agricultura tropical. Seropédica: Edur, 1998. 150p.

QUICK, W.P. sucrose metabolism in sources and sinks. In: ZAMSKI, E.; SCHAFFER, A.A. (Ed.) Photoassimilate distribution in plants. New York: Marcel Decker, 1996. p.115-156.

RICHARDO, C.P.P.; REES, T. Invertase activity during development of carrot roots. Phytochemistry, Oxford, v.9, p.239-247. 1970

ROITSCH, T.; EHNE $\beta$, R.; GOETZ, M.; HOUSE, B.; HOFMANN, M.; SINHA, A.K. Regulation and function of extracellular invertase from higher plants in relation to assimilate partitioning, stress response and sugar signalling. Australian Journal of Plant Physiology, Collingwood, v.27, p. 815-825, 2000.

ROITSCH, T.; BALIBREA, M.E.; HOFMANN, M.; PROELS, R.; SINHA, A.K. Extracellular invertases: metabolic enzyme and metabolic protein. Journal of Experimental Botany, Oxford, v.54, n.382, p. 513-524, 2003

SCHIER, A.A.; HOFFMANN-THOMA, G.; VAN BEL,A.J.E. Temperature effects on symplasmic and apoplasmic phloem loading and loadingassociated carbohydrate processing. Australian Journal of Plant Physiology, Collingwood, v.27, p.769-778, 2000.

SCHOLES, J.; BUNDOCK, N.; WILDE, R.; ROLFE, S. The impact of reduced vacuolar invertase activity on the photosynthetic and carbohydrate metabolism of tomato. Planta, Berlin, v.200, p.265272, 1996

TAKAYANAGI, ,T.; YOKOTSUKA, K. Relationship between sucrose accumulation and sucrose-metabolizng enzymes in developing grapes. American Journal of Enology and Viticulture. v.48, n.4, p403-407, 1997.

TYMOWSKA-LALANNE, Z.; KREIS, M. The plant invertases: physiology, biochemistry and molecular biology. Advances in Botanical Research, London, v.28, p-71-117, 1998. (não consta no texto)

YEMM, E.W.; WILLIS, ,A.J. The estimation of carbohydrates in plant extracts by anthrone. Biochemical Journal, London, v. 57, p.508$514,1954$.

ZUFFEREY, V.; MURISIER, F.; SCHULTZ, H.R. A model of the photosynthetic response of Vitis vinifera L. cvs Riesling and Chasselas leaves in the field: I. Interaction of age, light and temperature. Vitis, Siebeldingen, v.39, n.1, p.19-26, 2000. 